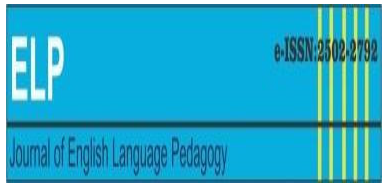

\title{
IDENTIFYING EFL STUDENTS' MOTIVATION TOWARDS READING ACTIVITY TO ENRICH THE CLASSROOM INTERACTION IN ELT CONTEXT
}

\author{
Ikrar Genidal Riadil \\ Universitas Tidar Magelang \\ Email : $\underline{\text { ikrargenidal21@gmail.com }}$
}

\begin{abstract}
Motivation is an inner condition that guides human behaviors towards a certain target. Motivation for learning is massively important, because the greater motivation that they have gained, the greater the learning outcomes of the learners. This research was done in the sense of low interaction in the classroom as learners seldom read a book, especially before attending to the lesson. The aim of this research also was to identify the encouragement of learners in reading activities to ensure classroom engagement in acquiring English as a foreign language (EFL). The researcher used descriptive qualitative approach. Firstly, the study, first, the researcher looked for the questionnaire of motivation to read. Secondly, the researcher selected the constructs or in this term, the questions categories to be used in this study. Thirdly, the researcher spread the selected questions as a questionnaire to the students of fifth semester of English Department in Tidar University. Then, after The researcher finished collecting the data, the researcher analyzed the results of the data obtained by asserting the students' motivation and interest by pursuing to read the literature review. Eventually, the researcher reported the results on the basis of the study evidence. Based on the findings, the researcher found that fifteen to twenty students like to read a challenging book if it is interesting because it makes the students to brainstorming to obtain the information even though it is hard to be understood. In conclusion, the researcher can conclude that the students' willingness of reading depended on their internal condition. They wanted to read if only the material or the book or the explanation is interesting and they get a compliment for their reading.
\end{abstract}

Keywords: EFL Learners, English Language Teaching, Reading, Students' Motivation, Classroom Interaction

\section{INTRODUCTION}

Language is an integral facet of human being. By studying the language, people will talk with one another, receive knowledge from one another and integrate amongst each other (Riadil, 2020). Language has a big role in human life to make a relation in their environment. One specialist notes whether language is commonly used throughout communicating with individuals who may not speak the same first (or even second) language (Harmer, 2007). Another expert stated that it also indicates that language is very important to learn in human life (Riadil, 2019). 
Furthermore, reading becomes more and more required in moderns' era. It's activities that could do every time in many ways. We read written items such as the message in our smart phone, magazine, advertisement, and newspaper. Reading also allows writers to gain more things and fresh skills after training. In line with Hinkel (2006), the term of reading distinguished as the fundamental and beneficial also the important skill to master in learning new information, and gain the access to get explanation, Interpreting and starting a polymerization of crucial assessment skills. Nowadays, reading become necessary device toward the English Foreign Language learners' growth their English proficiency level.

Moreover, reading is important to develop EFL learners in their socio-cultural competence. In education part, reading is one of Mandatory interventions for teachers and learners to do this all the moment. They may read many kind of texts based on their various purposes. Based on Hinkel (2006), they said that the basic skill to improve vocabulary, writing, fluency and speaking is reading. Thus would help the learners to master in their target language. Hence, no-brainer to decide that having good skill in reading important got successful students. Today, one of the popular topics in English second language learners in reading classroom is reading comprehension. In retrospect, reading the article in what seems like a foreign language as English is distinct than reading it in the first language. Presumably, English second-language readers usually had a plenty more reading knowledge in their first language. The important to comprehend the text by declare that reading means comprehending, (Rayner \& Reichle, 2010).

Consequently, one of the aspects which most necessary by English second language English learners is their ability to comprehend the texts (Riadil, 2020). Nevertheless, nowadays, the learners are try to solve in their reading problems. Davoudi \& Yousefi (2015), have classify reading difficulties and the problems that happen in EFL learners such as The problem of pupils in grammatical accuracy and poor comprehension in reading strategies is that they must be essential to support them minimize the significant problems, major issues in vocabulary knowledge and background knowledge (Samad, Jannah, \& Fitriani, 2017).

As cited from Cook \& Artino (2016), motivation is the inner state that leads the people's behavior to act for certain goal. Sometimes, it is interpreted as the needs, wants, or desires. According to Nurmadiah (2016) motivation is a series of efforts that provide certain conditions to make someone to do something. Based on the both definitions of motivation, we can infer that it is an internal condition that makes someone has a need, want, or wish to do something for achieving certain goals.

\section{Copyright (C) 2020, ELP, ISSN 2656-6451 EISSN 2502-2792}


Subsequently, students' motivation in learning is vital because the higher motivation they earned, the higher the students' learning outcomes. Thus, it is the key of a successful learning. Motivation pushes the student to have a willingness to do a meaningful learning. Meaningful learning results the long-term memorization. As a result, the student will comprehend the learned material well. There are literally some problems that found on students' motivation. One of them is the classroom interaction, the teacher might be used traditional way which is monotone in teaching learning, it affected the students' motivation, therefore, the students will feel bored especially in reading. Because reading is the most challenging skill and not many students interested or like to read a book. That is why the classroom interaction need to be more enlightening and interesting to make the students get enough motivation in reading.

In essence saying, there are four fundamental capabilities in English: listening skill, speaking skill, reading skill, and last writing skill. All these capabilities are basically train people in learning how to communicate and to deliver a message with others. Listening and reading are used to understand our worlds, whereas speaking and writing are to express our feelings, needs, and desires (Hinkel, 2006). Thus, it is important to master the four skills in English to be able to grasp the whole meanings of something. Since this study is focusing on motivation to read, this study will discuss on reading skill. The researcher tried to find the students' motivation that pushed them to have a willingness to read a topic or material.

According to Nunan (2003), Reading comprehension is the process that encompasses textual information with incontrovertible knowledge to construct layers of meaning. Thus, by combining the text information with the background of knowledge, it will let the reader to be able to build a meaning.

Meanwhile, Yan et al. (2018) also states that reading is the method of attaining or assembling meaning from a word or cluster of word. It means that, the reader gets something about what they have read before and they must be able to find the context of the text in order to understand the details of the text and develop its understanding.

\section{METHOD}

The researcher used a survey study approach in this study, the researcher have adapted the research method from another research entitled "Exploring the factors affecting MOOC retention: A survey study" by (Hone \& El Said, 2016). An online questionnaire was developed primarily using scales which have been used in previous research in a learning context. The 
questionnaire was written in English since English is the teaching language for undergraduates and postgraduates in most of Indonesian higher education institutes, including the one used as a context for this study. Demographic data was collected on age, gender, education and experience. At the end of the questionnaire there was space for participants to provide an open text response as to why they did or did not complete the course. Data was gathered through submitting questionnaires to respondents. The data collection procedures of this study were started by giving the questionnaire, asking the participants to fill in the questionnaire and finally the researcher compiled the questionnaire that had been answered.

This method is influenced by (Cam \& Tran, 2017). After the data have collected, it will be analyzed and recognized. Like what Cam \& Tran (2017) stated that the questionnaire is a quite useful collection method because researchers can reach many participants and respondents in a short time and it does not need cost so much.

\section{Questionnaire}

The researcher found a questionnaire of "Relations among intrinsic and extrinsic reading motivation, reading amount, and comprehension: a conceptual replication" that was developed by (Troyer et al., 2019). In their journal, they divided the questions into eleven categories/ constructs namely: Effectiveness of reading comprehension, reading conundrum, reading inquisitiveness, reading engagement, reading meaning and significance, reading prevention, reading competitive pressures, reading acknowledgement, level of reading comprehension, ethical reasons for reading, and adherence. In this study, the researcher chose five categories as shown in the table 1 below together with their questions:

Table 1. Questions' Category

\begin{tabular}{ll}
\hline Category & Questions \\
\hline Reading Challenge & 1. I love a good multidimensional, complex and difficult book. \\
2. Unless the idea is important, I may read a complicated piece of \\
content. \\
3. I like it because I talk about the issues throughout the books. \\
$\begin{array}{l}\text { 4. Invariably, I gain knowledge of complex and multidimensional } \\
\text { things by reading. } \\
\text { 5. If a book is fascinating, I wouldn't realize how tough it can be to } \\
\text { read it }\end{array}$ \\
\hline
\end{tabular}

4 Copyright (C) 2020, ELP, ISSN 2656-6451 EISSN 2502-2792 


\begin{tabular}{ll}
\hline Reading Curiosity & $\begin{array}{l}\text { 6. If the instructor is thinking about something essential, I could learn } \\
\text { so much about it. }\end{array}$ \\
$\begin{array}{l}\text { 7. I feel interested in reading to learn more about relevant topics to } \\
\text { me. }\end{array}$ \\
$\begin{array}{l}\text { Reading Work } \\
\text { Avoidance }\end{array}$ \\
$\begin{array}{l}\text { 8. I do not like when reading and found a word it is too complicated } \\
\text { to understand. }\end{array}$ \\
$\begin{array}{l}\text { Reading } \\
\text { Recognition for } \\
\text { Reading }\end{array}$ & $\begin{array}{l}\text { 10. I is essential for me to perceive my name on a list of reading } \\
\text { 11. I want to get feedback on my work. }\end{array}$ \\
\hline
\end{tabular}

The purpose of this research was to examine the encouragement of learners understanding and motivation in reading. The subjects were the students of English Department in Tidar University especially from the fifth semester. There were twenty-six respondents who answered the questionnaire given by the researcher. In the data analysis, this study was conducted by using descriptive qualitative approach.

Beginning the study, firstly, the researcher looked for the questionnaire of motivation to read and found it from Troyer et al. (2019) in "Relations among intrinsic and extrinsic reading motivation, reading amount, and comprehension: a conceptual replication" Secondly, the researcher selected the constructs or in this term, the questions category to be used in this study. Thirdly, the researcher spread the selected questions as a questionnaire to the students of fifth semester of English Department in Tidar University. After the researcher finished from collecting the data results, the researcher gathered data procured by clarifying the motivation of the students in reading the literature review. In a nutshell, the researcher came up with the conclusion based on the findings, results, and discussions of the study.

\section{FINDINGS AND DISCUSSION}

The researcher had spread a questionnaire of motivation in reading based on the "Relations among intrinsic and extrinsic reading motivation, reading amount, and comprehension: a conceptual replication" by (Troyer et al., 2019). The researcher did not use all of the question types that are eleven types in total but the researcher selected the five types of eleven. There are: Effectiveness of reading comprehension, reading conundrum, reading inquisitiveness, reading engagement, reading meaning and significance, reading prevention, reading competitive

\section{Copyright @ 2020, ELP, ISSN 2656-6451 EISSN 2502-2792}


pressures, reading acknowledgement, level of reading comprehension, ethical reasons for reading, and adherence. The data are shown below:

Table 2. Questionnaire of Motivation to Read

\begin{tabular}{cccccccccccc}
\hline Category & Q1 & Q2 & Q3 & Q4 & Q5 & Q6 & Q7 & Q8 & Q9 & Q10 & Q11 \\
\hline SA & 3.9 & 11.5 & 7.7 & 11.5 & 19.2 & 26.9 & 34.6 & 23.1 & 3.9 & 11.5 & 15.4 \\
\hline A & 61.5 & 65.4 & 50 & 65.4 & 53.8 & 65.4 & 65.4 & 53.8 & 42.2 & 65.4 & 61.5 \\
\hline D & 26.9 & 23.1 & 38.4 & 23.1 & 23.1 & 7.7 & 0 & 15.4 & 50 & 23.1 & 23.1 \\
\hline SD & 7.7 & 0 & 3.9 & 0 & 3.9 & 0 & 0 & 7.7 & 3.9 & 0 & 0 \\
\hline
\end{tabular}

Notes:

SA : Strongly Agree

A : Agree

D : Disagree

SD : Strongly Disagree

To make the analyzation become easier, the researcher simplified the answers of "agrees" and "strongly agrees" into "yes" category. Thus, the answers of "disagrees" and "strongly disagrees" are categorized as "no."

Table 3. Reading Challenge

\begin{tabular}{lccc}
\hline Question & YES & NO & Total \\
\hline Q1 & 18 & 8 & 26 \\
\hline Q2 & 20 & 6 & 26 \\
\hline Q3 & 15 & 11 & 26 \\
\hline Q4 & 20 & 6 & 26 \\
\hline Q5 & 19 & 7 & 26 \\
\hline
\end{tabular}


According to the table 3, from fifteen to twenty students like to read a challenging book if it is interesting because it makes the students to brainstorming to obtain the information even though it is hard to be understood. Meanwhile, from six to eleven students who do not like a challenging book as explained in the previous sentence. This is a condition that may be will cause the students to get confused when understanding a difficult information. Thus, the researcher assumed that the problems come from the ways the information and the questions of the book is delivered. Too many words arrangement in a sentence will make the students to take more time to understand and make them to re-read the previous related information if they find it.

Table 4. Reading Curiosity

\begin{tabular}{lccc}
\hline Question & YES & NO & Total \\
\hline Q6 & 24 & 2 & 26 \\
\hline Q7 & 26 & 0 & 26 \\
\hline
\end{tabular}

Based to the table 4 , the data shows that almost $99 \%$ students were motivated to read when the teacher discussed something interesting because it made the to have a willingness to read more about the teacher's explanation and obtain more information. However, there were two students who did not like to read more materials about the teacher's explanation. Thus, let us see back on the table 3's explanation. The students did not want to read when the book is hard to be understood. The researcher assumed that may be the students were interested about the teacher's explanation anyway but when seeing the truth that the book was hard to be understood, they prefer not to read more material.

Table 5. Reading Work Avoidance

\begin{tabular}{lccc}
\hline Question & YES & NO & Total \\
\hline Q8 & 20 & 6 & 26 \\
\hline
\end{tabular}

According to the table 5, the students did not like reading when the words are difficult. This reading work avoidance is almost the same as the reading challenge explanation in the part of difficult material. The researcher assumed that the difficult words in this term are the words 
that may be the students did not know the meaning yet or in other words, the student's vocabulary.

Table 6. Competition in Reading

\begin{tabular}{lccc}
\hline Question & YES & NO & Total \\
\hline Q9 & 12 & 14 & 26 \\
\hline
\end{tabular}

According to the table 6, seeing names on a list of the good readers seem does not proper to be applied. There were 14 students who disagree with this competition of reading. The researcher assumed that may be the students will feel uncomfortable when they see their name on the list but far away from the number one. May be they will be judged that they are a lazy person. This judgment actually can be their motivation to answer the problem but this is not appropriate for everyone since every person is unique. Luckily, there were 12 students saw the positive impact when they see their name on the good readers' list because they can use it as a motivation to push them to be the better students.

Table 7. Recognition for Reading

\begin{tabular}{lccc}
\hline Question & YES & NO & Total \\
\hline Q10 & 20 & 6 & 26 \\
\hline Q11 & 20 & 6 & 26 \\
\hline
\end{tabular}

According to the table 7, it seems like that the students will feel happy when their teacher says they read well. In other words, they like to have a compliment especially from their teacher. However, there are still twelve learners' disagreed with this. The researcher expected that may be they will get an indirect face threatening act from the teacher like the teacher gives a compliment to a student and says something good to the student and says something to other students that they should do the same thing and get a compliment. 


\section{CONCLUSION AND SUGGESTION}

To sum up, this research found that the students' willingness of reading depended on their internal condition. They wanted to read if only the material or the book or the explanation is interesting and they get a compliment for their reading.

In conclusion, to enhance the classroom interaction, the researcher suggests that the students should consider the positive effect of reading. As we can see from the question number 3, "I like it because I talk about the issues throughout the books" Actually, this is automatically directing to the positive thing because the students will brainstorm the meaning of the question to get what the students have to answer. However, the amount of the students who disagreed this questions reached almost 50\% where they disliked this type of question. The best way to get the meaning of a question is by doing a brainstorming where they relate the information with their background knowledge.

\section{REFERENCES}

Cam, L., \& Tran, T. M. T. (2017). An evaluation of using games in teaching English grammar for first year English-majored students at Dong Nai Technology University. International Journal of Learning, Teaching and Educational Research, 16(7), 55-71. Retrieved from https://pdfs.semanticscholar.org/ea44/48f1c6cbb8dab7420abbd20a993a86728206.pdf

Cook, D. A., \& Artino, A. R. (2016). Motivation to learn: an overview of contemporary theories. Medical Education. https://doi.org/10.1111/medu.13074

Davoudi, M., \& Yousefi, D. (2015). Comprehension Breakdown: A Review of Research on EFL Learners' Reading Difficulty and Problems. International Journal of Language and Applied Linguistics.

Harmer, J. (2007). The Practice of English Languag Teaching. 394-409.

Hinkel, E. (2006). Current Perspectives on Teaching the Four Skills. TESOL Quarterly. https://doi.org/10.2307/40264513

Hone, K. S., \& El Said, G. R. (2016). Exploring the factors affecting MOOC retention: A survey study. Computers and Education, 98, 157-168. https://doi.org/10.1016/j.compedu.2016.03.016

Nunan, D. (2003). Practical English Language Teaching. In McGraw-Hill Companies. https://doi.org/10.1017/CBO9781107415324.004

Nurmadiah, N. (2016). MEDIA PENDIDIKAN. Al-Afkar: Jurnal Keislaman \& Peradaban. https://doi.org/10.28944/afkar.v5i1.109

Rayner, K., \& Reichle, E. D. (2010). Models of the reading process. Wiley Interdisciplinary Reviews: Cognitive Science. https://doi.org/10.1002/wcs.68

9 Copyright (C) 2020, ELP, ISSN 2656-6451 EISSN 2502-2792 
Riadil, I. G. (2019). The EFL Learner's Perspectives About Accuracy, Fluency, and Complexity in Daily Routines. Journal of Research on Applied Linguistics, Language, and Language Teaching, 2(2), 160-166.

Riadil, I. G. (2020). DOES ORAL PRESENTATION AFFECT THE DEVELOPMENT OF THE STUDENTS'ABILITY TO SPEAK IN EFL CLASSROOM?. Social Sciences, Humanities and Education Journal (SHE Journal), 1(2), 13-21.

Riadil, I. G. (2020). INVESTIGATING EFL LEARNERS'READING COMPREHENSION PROBLEMS AND STRATEGIES IN TIDAR UNIVERSITY. JELLT (Journal of English Language and Language Teaching), 4(1), 48-58.

Riadil, I. G. (2020). Tourism Industry Crisis and its Impacts: Investigating the Indonesian Tourism Employees Perspectives' in the Pandemic of COVID-19. Jurnal Kepariwisataan: Destinasi, Hospitalitas dan Perjalanan, 4(2), 98-108.

Riadil, I. G. (2020). AN ANALYSIS OF ENGLISH MODALS IN MODAL VERB PHRASE STRUCTURES IN EDUCATIONAL ESSAYS OF 'SHERRY JOHNSON'AND 'TAMJID MUJTABA'. Jurnal Pendidikan Bahasa, 9(1), 131-142.

Samad, I. A., Jannah, M., \& Fitriani, S. S. (2017). EFL STUDENTS' STRATEGIES DEALING WITH COMMON DIFFICULTIES IN TOEFL READING COMPREHENSION SECTION. International Journal of Language Education. https://doi.org/10.26858/ijole.v1i1.2869

Troyer, M., Kim, J. S., Hale, E., Wantchekon, K. A., \& Armstrong, C. (2019). Relations among intrinsic and extrinsic reading motivation, reading amount, and comprehension: a conceptual replication. Reading and Writing. https://doi.org/10.1007/s11145-018-9907-9

Yan, S., Mollica, F., \& Tanenhaus, M. K. (2018). A context constructivist account of contextual diversity. CogSci 2018. 